important difference is that Bence Jones protein shows only one type of light chain, either $\alpha$ or $\lambda$, and there is considerable homogeneity within the type. In myeloma of Bence Jones type the myeloma cells produce only one form of light chain, but in other forms of myeloma a complete protein with both light and heavy chain components which will react with antisera to one of the immunoglobulin proteins is formed. This protein cannot perform any of the biological functions of the immunoglobulin which it resembles, and it is called a paraprotein. An example is seen in $\gamma \mathrm{G}$ myeloma, in which the patients are prone to infection though there is a considerable amount of $\gamma G$ paraprotein in the serum.

Paraproteins do not show the same variety of structure and function as immunoglobulins. When subjected to the influence of an electric field they migrate with one accord to form a distinct narrow band on electrophoresis-the so-called " $M$ " band.

Otto Kahler in 1889 described the clinical features of myelomatosis and recognized the association of bone destruction, anaemia, cachexia, and Bence Jones proteinuria as a clinical entity. In $1944 \mathrm{~J}$. Waldenström ${ }^{6}$ described a more benign condition in which an abnormal plasma protein, a macroglobulin, was formed and the patient was found to have anaemia, a tendency to bleed, and splenomegaly. This condition, called macroglobulinaemia, is, like myeloma, a clinical entity ; proliferation of a lymphocytoid cell is its pathognomonic feature. Since then, hawever, macroglobulinaemia has been seen in conditions such as leukaemia, reticuloses, carcinoma, and non-malignant conditions such as rheumatoid arthritis. The subject is made more confusing by findings of " $M$ " components in the absence of clinical evidence of disease. The results of prolonged and thorough surveys such as those by J. Hallen in 1966 and that recently reported by J. R. Hobbs show clearly that the finding of an " $M$ " component or paraprotein is not synonymous with diagnosing " myelomatosis" or Waldenström's macroglobulinaemia. Since Waldenström ${ }^{\circ}$ described patients in whose plasma " $M$ " components had been present for many years without deterioration in health others with "benign essential hyperglobulinaemia" have been reported.

Hallen found that patients with paraproteins of IgA or IgG type of a benign essential nature tended to have a low concentration of the paraprotein in the plasma, and that this became constant after a time. The absence of light chains in the urine in any excess was another favourable sign. In contrast, patients who eventually developed myeloma showed a steady increase in the level of paraprotein with time. Hobbs has emphasized the sinister significance of Bence Jones proteinuria, particularly in those patients with a $\gamma \mathbf{M}$ type of " $M$ " component. A level of $1 \mathrm{mg} / 100 \mathrm{ml}$. of urine appears to be significant. Increasing production implies a worse prognosis. In addition, he has shown that maintenance of the level of the other normal immunoglobulins within normal limits suggests a benign course. The mechanism whereby the production of paraprotein in malignant conditions inhibits normal immunoglobulin production is not clear but is of fundamental importance.

Gitlin, D., Ann. Rev. Med., 1966, 17, 1.

: Fudenberg, H. H., Ann. Rev. Microbiol., 1965, 19, 301.

- Heremans, J. F., Clin. Chim. Acta, 1959, 4, 639.

- Grabar, P., and Williams, C. A., Biochem. Biophys. Acta, 1953, 10, 193.

- Porter, R. R., Biochem. Y., 1959, 73, 119.

- Parter, R. R., Joc Acta med. scand,, 1944, 117, 216.

'Hallen, J., Acta med. scand., 1966, Suppl. No. 462.

- Hobbs, J.' R., Brit. mod. Y., 1967, 3, 699.

- Valdenström, J., Advanc. interm. Med., 1952, 5, 398.

\section{Vagotomy in Treatment of Duodenal Ulcer}

Though still the subject of debate, vagotomy combined with some type of operation for gastric drainage has become firmly established in many centres all over the world in the surgical treatment of duodenal ulceration. Indeed, the number of patients who have now undergone this treatment must be numbered in tens of thousands. Several long-term followup studies have shown that satisfactory results with acceptably low operative mortality can be expected. ${ }^{1-5}$ Even gross pyloric stenosis, once considered a contraindication to the operation, has now been shown to respond admirably to vagotomy and drainage.

Two important questions are still debated. Firstly, how does vagotomy compare with the old-established operation of partial gastrectomy with gastrojejunal anastomosis, the socalled Polya operation, with all its many modifications? Secondly, what is the cause of the diarrhoea which may follow vagotomy and drainage, and how is it to be prevented ?

$\mathrm{J}$. Goligher and his colleagues ${ }^{7}$ have compared vagotomy and gastrojejunostomy, vagotomy with antrectomy, and the Polya partial gastrectomy in a prospective trial in Leeds. The differences in the results of the three operations proved to be small, dumping being commoner in the patients who had gastrectomy and diarrhoea commoner in those who had vagotomy. A. G. Cox ${ }^{8}$ has recently studied 55 patients after partial gastrectomy and 51 after vagotomy with a gastrojejunostomy. The latter had marginally better results than the former in terms of alimentary symptoms. Thirteen of the patients with vagotomy and nine of those with gastrectomy had episodic diarrhoea, but the frequency and severity of the attacks seemed about the same among those affected in both groups.

At least some patients develop diarrhoea after every type of gastric operation. Since this is a symptom which requires thorough evaluation, its exact incidence after vagotomy and drainage has been the subject of much discussion. Whittaker and his colleagues ${ }^{5}$ report from the Mayo Clinic on 436 patients followed up on an average for seven years after vagotomy and various drainage procedures. Though 61 patients $(14 \%)$ had mild diarrhoea, only two had diarrhoea so frequent as to require medication. Perhaps the most careful analysis of bowel disturbance after vagotomy was that of Cox and M. R. Bond, ${ }^{9}$ who studied 100 patients approximately four years after vagotomy and gastrojejunostomy. Daily bowel frequency was increased in 71, episodic

1 Holt, R. L., and Lythgoe, J. P., Brit. F. Surg., 1961, 49, 255.

, Holt, R. L., and Lythgoe, J. P., Brit. Y. Surg., 1961, 49, 255

3 Tanner, N. C., Brit. Y. Surg., 1966, 53, 185.

- Schofield, P. F., Watson-Williams, E. J., and Sorrell, V. F., Arch. Surg., 1967, 95, 615 .

- Whittaker, L. D., Judd, E. S., and Stauffer, M. H., Surg. Gymec. Obstet., $1967,125,1018$.

- Ellis, H., Proc. roy. Soc. Med., 1967, 60, 745.

- Goligher, J., Pulvertaft, C. N., and Franz, R. C., Conference on Postgraduate Gastroenterology, ed. T. J. Thomson and I. E. Gillespie, graduate Chapt. 26. London.

- Cos, A. G., Brit. med. Ұ., 1968, 1, 288.

Cox, A. G., Brit. med. F., 1968, 1, 288.

10 Kraft, R. O.,, Kirsh, M. M., Kittleson, A. C., Ernst, C. R., Pollard, H. M., and Ransom, H. K.. Surg. Gynec. Obstet., 1965, 120, 472.

1 Williams, E. J., and Irvine, W. T., Lancet, 1966, 1, 1053.

12 Bastable, J. R., G., Brit. Ұ. Surg., 1965, 52, 459.

1s Kraft, R. O., Fry, W. J., and Ransom, H. K., Arch. Surg., 1962, 85, 687.

14 Ellis, H., and Pryse-Davies, J., Brit. 7. exp. Path., 1967, 48, 135.

15 Tucker, F. H., Barnett, W. O., and Goodrich, J., Surg. Gynec. Obstet. 1964, 118, 1281.

16 Wasteli, C., Brit. med. Y., 1966, 1, 1198.

17 Wastell, C., and Ellis, H., Brit. med. .., 1966, 1, 1197.

Kraft, R. O., Fry, W. J., Wilhelm, K. G., and Ransom, H. K., Arch. Surg., 1967, 95, 625. 
diarrhoea developed in 23 , transient diarrhoea in 10 , and a tendency to constipation in 5 . Only 8 of the patients in the whole group were disappointed in their bowel condition, 3 because they now suffered from constipation. No fewer than 55 of the patients were actually pleased with their increased frequency of bowel action. The same authors collected data from 25 papers on the incidence of diarrhoea after vagotomy and found an overall figure of about $2 \%$ of troublesome diarrhoea.

The cause (or perhaps causes) of this post-vagotomy diarrhoea, which is often episodic, remains a mystery. It is tempting to blame the denervation of the rest of the gastrointestinal tract and its adnexae which must inevitably accompany total division of the main vagal tracts as they enter the abdomen. Yet extensive investigations have failed to show convincing evidence of disturbed biliary, ${ }^{10} 11$ pancreatic, ${ }^{12}$ or small-intestinal function. ${ }^{13} 14$ Nor have many careful studies, both clinical and experimental, shown any significant metabolic, absorptive, or radiological differences in either men or dogs undergoing total vagal division or selective vagotomy in which either the coeliac or the hepatic or both these branches of the vagus have been preserved. ${ }^{10} 11$ 15-18 In spite of these findings several surgeons have staunchly advocated the preservation of the coeliac and hepatic tracts of the vagus as a method of preventing post-vagotomy diarrhoea. In Great Britain Mr. Harold Burge has long championed this cause, and in this issue of the B.M.F. (page 481) he and his colleagues put forward a strong case for bilateral selective vagotomy. And they add: "We believe it more reasonable to think that post-vagotomy diarrhoea is caused by denervation of organs other than the stomach rather than by denervation of the stomach itself. Because no functional disturbance of these extragastric organs can be found after total abdominal vagotomy, it must not be concluded that when denervated they are not to blame for this complication." This contribution will give food for thought and perhaps encourage still further studies, both clinical and experimental, in this important field.

\section{Nail-gun Injuries}

Working at his desk on the eleventh storey, a bank clerk felt a sudden piercing pain in the left arm and chest. Looking down, he saw blood and collapsed. Investigation showed that he had been hit in the chest with a stud fired by a blank cartridge from a building site across the street. This type of accident has been reported from Germany, ${ }^{12}$ America, ${ }^{3}$ the Soviet Union, ${ }^{4}$ and Great Britain, ${ }^{5-11}$ where cartridgeoperated fixing-tools (nail guns) have been in common use for about 14 years. A letter in our correspondence columns (p. 511) draws attention to the lack of effective measures for the control of these dangerous tools.

\footnotetext{
Staudacher, F. X., Mschr. Unfallheilk., 1960, 63, 17.

Russe, O., Klin. Med. (Wien), 1960, 15, 220.

Mage, S., and Sze, K. C., New Engl. F. Med., 1962, 267, 1020

Zverev, A. F., Vestn. Khir., 1964, 93, 92.

- Klenerman, L., Brit. med. F., $1961,2,1785$.

- Oldfield, M. C., Brit. med. \%., 1962, 1, 262

Wilson, P. J. E., Brit. med. F., 1962, 1, 341.

- Cragg, J., Brit. med. F., 1967, 4, 784.

- McMillan, I. K. R., Brit. med. f., 1968, 1, 181

10 Spencer G. T., Brit. med. ₹., 1968, 1, 181 .

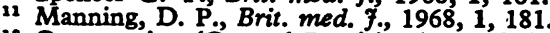

12 Construction (General Provisions) Regulations, S.I. 1580/1961; Working Places Regulations, S.I. 94/1966. H.M.S.O.

18 Wander, R., The Illustrated Carpenter and Builder, 1967, 156, 194.

14 Ministry of Works Advisory Leaflet No. 53, 1962. H.M.S.O.

1s Specification for Cartridge-Operated Fixing Tools, 1966, British StanSpecification
dards 4078 .
}

Some of these guns have a muzzle velocity of up to $1,400 \mathrm{ft}$. $(430 \mathrm{~m}$.) $/ \mathrm{sec}$ - - a $0.22 \mathrm{in}$. (6 mm.) rifle has a muzzle velocity of about $1,145 \mathrm{ft}$. $(350 \mathrm{~m}$.)/sec. - and the injuries which have been reported are often severe, because the sharp, highvelocity projectiles, designed to penetrate masonry or wood, may enter deeply into the thorax or abdomen. They can do so after traversing a $10-\mathrm{cm}$. brieze wall ${ }^{3}$ or a brick wall (travelling in the mortar between bricks), ${ }^{9}$ or after ricocheting off hard material such as concrete. ${ }^{6}$

In Britain nearly all the accidents reported from these tools have resulted from activities on building sites, and the victims have usually been workers on the sites. The responsibility for the enforcement of statutory safety measures in this area rests with the Factory Inspectorate of the Ministry of Labour, but at present the only statutory requirement is that explosives should be handled or used by, or under the immediate control of, a competent person. ${ }^{12}$ It would seem that such a regulation was intended for quite different circumstances. Furthermore, it is possible that cartridge-operated fixing-tools may be used on premises that are not legally "factories" and to which the requirements of the Factories Act do not apply. If such use is widespread it may be asked whether such activities are covered by any wider legislation.

R. Wander ${ }^{13}$ has recently reviewed the safety of these appliances, and the Ministry of Works has issued an advisory leaflet. ${ }^{14}$ The British Standards Institute has issued a Specification for Cartridge-operated Fixing Tools. ${ }^{15}$ It recommends that the tools should incorporate a splinter guard to withstand ricochet and to retain flying pins, that tools should fire only when the barrel and splinter guard are pressed against the fixing surface with a pressure of not less than $5 \mathrm{~kg}$., and that they should not fire when the angle formed between the perpendicular and the axis of the tool is greater than $7^{\circ}$. An appendix to the specification gives commonsense recommendations for the use of cartridge-operated fixing-tools. The pins should not be driven into brittle or hard materials such as vitreous-faced bricks or hardened steel. They should not be driven into structures where there is a risk of their passing through, unless special precautions are taken. Operators of fixing-tools should receive adequate training, and persons less than 18 years of age should not be permitted to use them.

Such a British Standard has no legal force. The recent reports of accidental injury pose the question whether the time has come for stricter legislative control. The recommendations of the British Standard would form a useful basis for a statutory code.

\section{Dental Anaesthesia}

Over the past 20 years it has become apparent that the arrangements for general anaesthesia in dentists' surgeries are sometimes less than perfect. This uneasiness coincided with the explosive post-war growth of interest in anaesthesia in general, and, as a result, general anaesthesia for dental surgery received a close look by experts in anaesthesia who brought to it standards of comparison and assessment which were hitherto unknown. General anaesthesia for dentistry, like anaesthesia for other kinds of surgery, had been regarded for nearly 100 years as a matter of technique alone, the acquisition of which was all that was necessary for a satisfactory performance. It is now accepted that anaesthetists must, in addition, be knowledgeable about a wide range of basic medical subjects, of which physiology and pharmacology are two of the most 